\title{
Comparative Modulation of the Reproductive System by Ethanolleaf Extracts of Asystasia Gangetica And Anthocleista Vogelli in Male Wistar Rats
}

\author{
S. I. Egba, C. O. Okonkwo, H. C. Omeoga, and I. E. Ekong
}

\begin{abstract}
A number of medicinal plants have been found to influence the level of reproductive hormones and thus affect fertility in the overall. This work evaluated the effects of ethanol leaf extracts of $A$. gangetica and $A$. vogelli respectively on some reproductive system parameters in male Wistar rats. A total of sixteen (16) male albino rats were grouped into four (four rats in each group): group A served as normal control, group $B$ received Immunace (Vitabiotics) group $C$ and $D$ received $400 \mathrm{mg} / \mathrm{kg}$ body weight of $A$. gangetica and $A$. vogelli extracts respectively. Extracts were administered orally to rats for 21 days, after which they were sacrificed by cervical dislocations and blood samples drawn by cardiac puncture. The effect of the extracts on testosterone, follicle stimulating hormone, luteinizing hormone and semen analysis of the test rats were determined using enzyme linked immunosorbent assay (ELISA) and standard techniques. Data collected were analyzed using Graph pad prism V6 and $p$ values $<0.05$ were adopted as significant. There was no significant $(p>0.05)$ change in testosterone, FSH and luteinizing hormones in the group administered $A$. gangetica plant extract relative to the control. There was also no visible difference in the testes weight and sperm morphology relative to the control group. In contrast, administration of $A$. vogelli extract caused significant $(p<0.05)$ decrease in testosterone and follicle stimulating hormone concentrations from: $1.12 \pm 0.20$ to $0.89 \pm 0.05$ and $1.41 \pm 0.07$ to $1.35 \pm 0.12$ respectively relative to the control group. While significant $(\mathbf{p}<\mathbf{0 . 0 5})$ decrease in luteinizing hormone $(1.71 \pm 0.15)$ was observed relative to the standard drug group $(1.76 \pm 0.05)$. A significant $(p<0.05)$ decrease in sperm count and testes weight was also observed in rats treated with $A$. vogelli extract relative to the normal control.The results suggest that, $A$. vogelli extract may cause decreased fertility in male albino rats and could be developed further into potent male contraceptives. $A$. gangetica on the other hand, had no effect on male reproductive hormones.
\end{abstract}

Keywords-Anthocleistavogelii, Asystasia gangetica, modulatory, reproductive.

\section{INTRODUCTION}

A condition where couples engage in regular unprotected sex for a period lasting up to 12 months is deemed infertility[1]. The cause of infertility can be of female, male or mixed origin. Male infertility is diagnosed generally on the basis of semen analysis including sperm concentration,

Published on May 30, 2020

S. I. Egba, Department of Biochemistry, College of Natural Sciences, Michael Okpara University of Agriculture, Umudike, Abia State, Nigeria. (corresponding email:egba.simeonikechukwu@gmail.com)

C. O. Okonkwo, Department of Biochemistry, Faculty of Basic Medical Sciences, University of Calabar, Nigeria. (email: oko210love@gmail.com)

H. C. Omeoga and I. E. Ekong, Department of Biochemistry, College of Natural Sciences, Michael Okpara University of Agriculture, Umudike, Abia State, Nigeria. (email: omeoga.humphrey@gmail.com) morphology, motility and vitality. Plant extracts are now increasingly used as fertility enhancer in humans [2]. This is so especially in developing countries due to ease of accessibility and affordability [3], [4]. Several plants have found usage in managing male infertility [5]. The parts of these plants that are used include the roots, bark and fruits which are either boiled or taken as drinks or chew in the raw state.

Plant extracts are greatly desired and explored today as remedy for numerous medical conditions because they are seen as natural products which are generally deemed safer than synthetic remedies [6].

Anthocleista vogelli and Asystasia gangetica are among plants known to have medicinal potentials in many parts of Africa [7].Some plants are known to modulate the immune system while others with no history of roles in ethnomedicine are being investigated for possible medicinal values [8], [9]. Several plants have been found to possess aphrodisiac properties [10] and exploited as such. It is interesting to observe that while a number of plants enhance male fertility, others inhibit it [11]. The later can be developed into natural product based male contraceptive.Avogelii is one of the plants used traditionally in the management of infertility in humans [12]

Male infertility is on the increase accounting for up to $50 \%$ in some instances in Nigeria [13]. The reproductive processes require excellent integrity and interactions between the female and male reproductive systems for conception to take place.

A.vogelii belongs to the family Loganiaceae[14]. In Nigeria it is known by different names in different places such as "Saposapo" "kwari" and "mpoto" by the Ijebu, Hausa and Igbo tribes respectively [15].

Testosterone, follicle stimulating hormone (FSH) and luteinizing hormone $(\mathrm{LH})$ all play very important roles in male reproductive processes [16], [17].Follicle stimulating hormone (FSH) is involved in the regulation of several essential reproductive processes occurring at the gonadal level which synthesize and secrete male and female sex hormones [18]. The level of luteinizing hormone (LH) and follicle stimulating hormone (FSH) is controlled by the pituitary gland and which in turn controls the stimulation or otherwise of testes and testosterone/sperm production [19].

This study aims at evaluating the effect of ethanol leaf extracts of $A$. gangetica and A.vogelii respectively on some reproductive hormones in male Wistar rats in order to justify their use in folklore. 


\section{MATERIALS AND METHODS}

\section{A. Reagents}

The assay kits for testosterone, follicle stimulating and luteinizing hormones were manufactured by Biocheck Inc., Foster City, CA. USA.

\section{B. Collection and Identification of Plant Materials}

Fresh leaves of $A$. gangetica and A. vogelliwere collected from the University forest in Michael Okpara University of Agriculture, Umudike (MOUAU), Abia state Nigeria; they were identified by a botanist in the Department of Plant Science and Biotechnology, MOUAU, after which they were air-dried and ground into powder. A known weight $(200 \mathrm{~g})$ of each sample was weighed out and soaked in 1000 $\mathrm{mL}$ of ethanol of analytical grade and allowed to stand for 48 hours. The solutions obtained from both plants were filtered using Whatman filter paper. A clear amber coloured filtrate was obtained from A. gangetica and a brownish coloured filtrate for $A$. vogelli; these were collected into clean empty beakers. The filtrates were evaporated to dryness in a water bath at $40^{\circ} \mathrm{C}$ for 36 hours until a semisolid residue (brownish black slurry) was obtained and the percentage yield calculated.

\section{Experimental Animals}

Male albino rats(Rathusnorvegieus) of Wistar strain aged $7-10$ weeks weighing $100 \mathrm{~g}-140 \mathrm{~g}$ were purchased from the animal breeding unit of the College of Veterinary Medicine, University of Nigeria, Nsukka, Enugu state, Nigeria. The rats were housed in a well-ventilated stainless steelcages under tropical conditions and exposed to 12hour light/dark cycles in the animal breeding housing Department of Biochemistry, College of Natural Sciences (COLNAS) Michael Okpara University of Agriculture , Umudike, Abia State Nigeria. They were allowed free access to water and fed with normal commercial pelletized feed (Feeds and Flour Mills Ltd, Ewu, Nigeria). They were acclimatized for one week before the commencement of the experiment.

GROUP 1: Served as normal control, were given feed and water only.

GROUP 2: received the standard drug (Immunace;modified for rats)

GROUP 3: received ethanol extract of $A$. gangeticaleaves (400mg/k body weight)

GROUP 4: received methanol extract of $A$.

vogellileaves $(400 \mathrm{mg} / \mathrm{kg}$ body weight)

The treatments were given once daily for 21 days using intubation tube. At the end of 21 days, rats were starved overnight then anaesthetized and through cardiac puncture, $4 \mathrm{ml}$ of the blood was collected clean and dry centrifuge tubes. The blood was then left to stand for 30 minutes at room temperature. The tubes were thereafter centrifuged at $3000 \mathrm{~g}$ for 10 minutes using Uniscope Laboratory Centrifuge (Model SM800D, Surgifriend Medicals and Essex, England). The sera were later aspirated with Pasteur pipettes into plain tubes and kept refrigerated at $\left(4^{\circ} \mathrm{C}\right)$ and used within 12 hours for the assay.

\section{Determination of Biochemical Parameters}

The concentration of hormones; testosterone, FSH and LH were measured in serum by ELISA method using standard kits (Biocheck, Inc. Foster City CA USA) was used. The procedure described in the hormone assay kits was used according to the principle highlighted by Tietz [20] and Uotilaetal.[21].

\section{E. Statistical Analysis}

Data were collected and expressed as mean \pm standard deviation, and then analyzed using Graph pad prism V6 and $\mathrm{p}$ values $<0.05$ were adopted as significant.

\section{RESULTS}

Testosterone

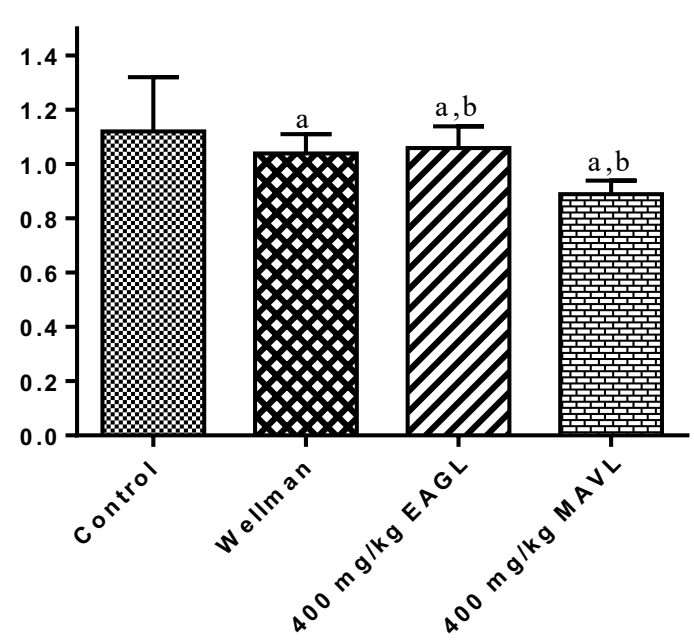

Fig. 1. Effect of EAGL and MAVL on testosterone in rats $a-$ non-significantly $(p>0.05)$ different from control $\mathrm{b}$ - non-significantly different from Wellman EAGL - Ethanol extract of $A$. gangetica leaves MAVL - Ethanol Extract of A.vogelii leaves

Follicle Stimulating Hormone

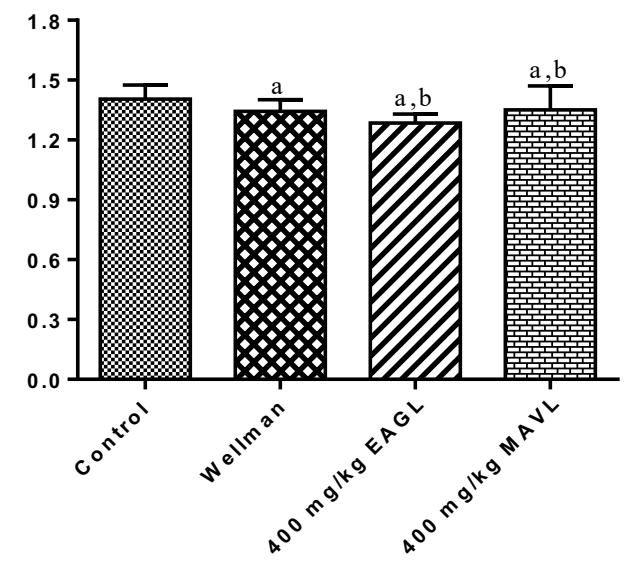

Fig. 2. Effect of EAGL and MAVL on follicle stimulating hormone in rats $a-$ non-significantly $(p>0.05)$ different from control $\mathrm{b}$ - non-significantly different from Wellman EAGL - Ethanol extract of $A$. gangetica leaves MAVL - Ethanol Extract of A.vogelii leaves 


\section{Luteinizing Hormone}

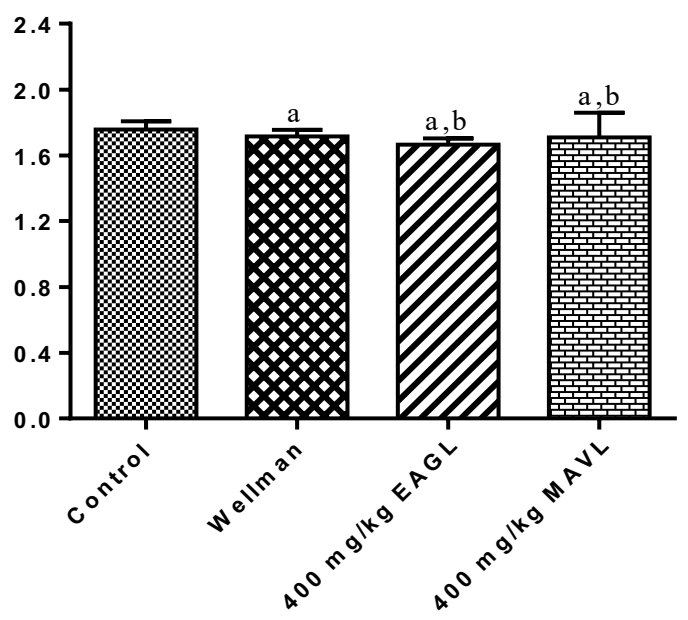

Fig. 3. Effect of EAGL and MAVL on luteinizing hormone in rats $a-$ non-significantly $(p>0.05)$ different from control

$\mathrm{b}$ - non-significantly different from Wellman

EAGL - Ethanol extract of $A$. gangetica leaves

MAVL - Ethanol Extract of A.vogelli leaves

TABLE I: EFFECT OF EAGL AND MAVL ON SPERM MORPHLOGY IN RATS

\begin{tabular}{lllll} 
& \multicolumn{4}{c}{ GROUPS } \\
\cline { 2 - 5 } & Control & Wellman & $\begin{array}{l}400 \\
\text { mg/kg } \\
\text { EAGL }\end{array}$ & $\begin{array}{l}\text { MAVL } \\
\text { EAg/kg }\end{array}$ \\
\hline Sperm & $58.00 \pm$ & $50.50 \pm$ & $60.00 \pm$ & $45.5 \pm 1.91^{\mathrm{b}}$ \\
count (\%) & 0.81 & $0.95^{\mathrm{a}}$ & $0.81^{\mathrm{a}, \mathrm{b}}$ \\
Active & $65.50 \pm$ & $67.00 \pm$ & $62.50 \pm$ & $49.5 \pm$ \\
cells (\%) & 2.06 & $2.38^{\mathrm{a}}$ & $2.50^{\mathrm{a}, \mathrm{b}}$ & 11.00 \\
Sluggish & $34.50 \pm$ & $33.00 \pm$ & $37.50 \pm$ & $50.0 \pm$ \\
cells (\%) & 2.06 & $2.38^{\mathrm{a}}$ & $2.50^{\mathrm{a}, \mathrm{b}}$ & 11.54 \\
Normal & $67.00 \pm$ & $59.50 \pm$ & $50.00 \pm$ & $39.5 \pm$ \\
cells (\%) & 2.38 & $3.77^{\mathrm{a}}$ & $2.50^{\mathrm{b}}$ & 11.00 \\
Abnormal & $33.00 \pm$ & $40.50 \pm$ & $50.00 \pm$ & $59.5 \pm$ \\
cells $(\%)$ & 2.38 & $3.77^{\mathrm{a}}$ & $2.50^{\mathrm{b}}$ & 12.15 \\
Testes & $1.84 \pm$ & $1.87 \pm$ & $1.24 \pm$ & $1.20 \pm$ \\
weight & 0.30 & $0.10^{\mathrm{a}}$ & $0.17^{\mathrm{a}, \mathrm{b}}$ & $0.56^{\mathrm{a}, \mathrm{b}}$ \\
\hline
\end{tabular}

$a-$ non-significantly $(\mathrm{p}>0.05)$ different from control

$\mathrm{b}$ - non-significantly different from Wellman

EAGL - Ethanol extract of A. gangetica leaves

MAVL - Ethanol Extract of A.vogelii leaves

\section{DISCUSSION}

Herbal preparations have been used by man for therapeutic purposes since time immemorial [22]. Several bioactive compounds of plant origin have been shown to have the capacity to interfere with the reproductive cycle [23].

Our results (figure 1-3) showed a slight decrease in some reproductive hormones. Amidu et al. [24] had earlier reported that alcoholic extract of A gangetica had antifertility effect in rats at high concentration. In our study, the observed difference was not significant enough to cause changes in rats administered extract of A. gangetica. This shows very clearly that the extract may not be a good candidate for making pro fertility drugs in male rats but may be useful as contraceptives at high concentrations. This is further reinforced by the significant adverse effect on semen analysis of the test rats (table 1).Reduction in male reproductive hormones may have been caused by saponins in the extract. Saponins have been shown to cause reduction in testosterone levels through its androgens lowering action [25], [26].

The decrease in sexual hormones and other biochemical indices of sexual viability analyzed in rats treated with A. vogelli extract indicates possible induction of infertility in male Wistar rats. Since FSH is directly linked with spermatogenesis [27], it is understandable that its decrease was similarly associated with similar decline in all other indices of sexual viability analyzed. Distortion of testicular cells affect spermatogenesis and apparently affect the quality and quantity of sperm cells. It thus suggests that the treatment had a significant distortion on the testicular cells of the rats that led to the decrease in sperm count observed.

Luteinizing hormone (LH) stimulates secretion of sex steroids from the gonads [24]. Substances capable of interfering adversely with the level of LH will consequentially have negative effect on steroidogenesis. Some medicinal plants cause decrease in sperm count, sperm viability, sperm motility and reproductive hormones by disrupting spermatogenic pathways [28]. This may be the case in our study, as A. vogelli decreased the sperm count of rats significantly. The leaf of A. vogelli contains important bioactive components [29] whose effect can singly or synergistically enhance the biosynthetic processes underlying hormonal production.

Undoubtedly, the consumption of A. vogelli, especially in the rural villages could result in a compromised reproductive system. Implicitly, administration of the leaf of A. vogelli caused a decrease in the viability and sperm output of the male albino rats as well as abnormalities on the sperm head of the rats. Administration of some plant extracts may adversely affect sperm motility and fertility generally in rats [30]. Based on findings from this study, it is obvious that the administration of A. vogelli may negatively affect fertility hormones of male Wistar rats.

\section{CONCLUSION}

A. gangetica caused no significant change in sexual hormones but caused significant difference in sperm morphology (Table 1). It may thus have a negative effect on the reproductive system of the male rat, and could be considered as a possible candidate for the production of male contraceptives. A.vogelli on the other hand, reduced the concentrations of sexual hormones and sperm viability.It could thus be exploited in the manufacture of male contraceptive pills, since it is also practically safe and nontoxic to rats.

\section{SIGNIFICANCE STATEMENT}

This study has uncovered the possible use of leaf extracts of A vogelli as a natural male contraceptive agent. There is need to extract the actual bioactive compound responsible for this observed effect and purify it for optimum effect alone or in combination with other compounds. 


\section{REFERENCES}

[1] F. Ghaffari, and A. Arabipoor. The role of conception type in the definition of primaryand secondary infertility. Int $J$ Reprod Biomed (Yazd), vol. 16, no. 5, pp. 355-356, 2018.

[2] A.A. Dada and V.O Ajilore. Use of ethanol extracts of Garcinia kola as fertility enhancerin female catfish Clariasgariepinusbroodstock. International Journal Fish and Aquaculture., vol. 1, no. 1, pp. 005-010, 2009.

[3] M. Ganguly, M. Borthakur, N. Developmenti, R. Mahanta. Antifertility activity of the methanolic leaf extract of Cissampelospareira in female albino mice. J. Ethnopharmacol., vol. 111, pp. 688-691, 2007.

[4] L. K. Merlin, G. K. Mensah, D. F. Arnold, F. Caleb, K. A. Alexande and A. D. Rita. Toxicity and Safety Implications of Herbal Medicines Used in Africa, Herbal Medicine, Philip F. Builders, IntechOpen, 2019

[5] M. M. Burns. Alternative medicine: Herbal preparation. Clinic Emergency Medicals, vol. 1, pp. 186-190, 2000.

[6] N. Desai, R. Sharma, K. Makker and E.A.A Sabannegh. Physiologic and pathologic levels of reactive oxygen species in neat semen of infertile men. Fertilizer Sterilization, vol. 92, pp. 1626-1631, 2009

[7] J. E. Otoide. Preliminary Inventory of the Vegatation at the proposed site of the Ekiti State University Botanical Garden. World News of Natural Sciences. vol. 24, pp. 36-53, 2019.

[8] O. S. Adedeji, G. O. Farimi, S. A. Ameen and J. B. Olayemi. Effects of bitter kola (Garcinia kola) as growth promoter in Broiler Chicks fromday old to four weeks old. Journal Animal Veterinary, vol. 5, no. 3, pp. 191-193, 2009.

[9] G. K. Anjana, S. Dilip, K. Sandeep and K. B. Ashok. Immune modulating property of Ocimum sanctum by regulating the IL-2 production and its mRNA expression using rat's splenocytes. Asian Pacific Journal Tropical Medication, vol. 3, no. 1, pp. 8-12, 2010.

[10] S. H. Kotta, A. Shahid, and J. Ali. Exploring scientifically proven herbal aphrodisiacs. Pharmacog Rev, vol. 7, no. 13, pp. 1-10, 2013.

[11] P. S. Shajeela, V. R. Mohan, J. L. Louis and S. P. Tresina. Antifertility acitivity of ethanol extract of Dioscorea esculenta (L.) Schott on male albino rats. Int J PharmTech Res, vol. 3, no. 2, pp. 946-954, 2011.

[12] S. O. Oladimeji, J. O. Igbalaye and C. L. Coleshowers. Immunological biomarkers determined in female rats administered with pro-fertility extract ofAnthocleistavogelliJournal National Science Resource, vol. 4, pp. 113-123, 2014.

[13] O. A. Esimai, E. O. Orji and A. R. Lasisi. Male contribution to infertility in IIe-Ife, Nigeria. Nigeria Journal of Medicine, vol. 11, no. 2 , pp. $70-72,2002$

[14] I. A. Jegede, J. A. Ibrahim and O. F. Kunle. Phytochemical and pharmacognostic studies of the leaf and stem-bark of Anthocleista vogelli (Planch). Journal of Medicinal Plants Research,vol.5, no. 26, pp. 6136-6139, 2011.

[15] G. O. Anyanwu, E. C. Onyeneke, U. Usunobun and A. J. Adegbegi. Impact ofAnthocleistavogelliroot bark ethanolic extract on weight reduction in high carbohydrate diet induced obesity in male wistar rats. African Journal of Biochemistry Research, vol. 7, no. 11, pp. 225-232, 2013.

[16] E.G. Nieschlag, F. Weinbauer, T. G. Cooper, W. Wittkowski and T. Cantz. Reproduktion. In: Speckmann E-J, Hescheler J, Köhling R (eds.) Physiologie 5. Auflage, Urban \& Fischer München pp. 652-677, 2008.

[17] G. F. Weinbauer, C. M. Luetjens, M. Simoni, and E. Nieschlag. Physiology of Testicular Function. In: Nieschlag, E., Behre, H.M., Nieschlag, S. (edition). Andrology-Male Reproductive Health and Dysfunction $3^{\text {rd }}$ eddition . Verlag Berlin Heidelberg : Springer pp.11-60, 2010

[18] S. R. Babu, M. D. Sadhnani, M. Swarna, P. Padmavathi and P. P. Reddy. Evaluation of FSH, LH and testosterone levels in different subgroups of infertile males. Indian J Clin Biochem, vol. 19, no. 1, pp. 45-9, 2004.

[19] N. N. Tietz. (Ed). Clinical Guide to Laboratory Tests. $3^{\text {rd }}$ Ed. Philadelphia: W.B Saunders Pp 216-217, 1995.

[20] M. E. Uotila and E. Ruoslahti. Radioassay System in Clin. J. Immunol. Methods, vol. 42, pp. 11, 1981.

[21] Y. E. Ameyaw, S. Duker, D. George and S. D. Mills-Robertson. Assessment of Variation in Some Medicinal Plant Species. Ethno biological Leaflets, vol. 1, no. 12, pp. 1-6, 2008.

[22] J. O. Moody, V. A. Robert, J. D. Connolly and P. J. Houghton. Anti-inflammatory activities of the methanol extracts and an isolated furanoditerpene

constituent

of

SphenocentrumjollyanumPierre

(Menispermaceae),J.Ethnopharmacol. vol. 104, pp. 87-91, 2006

[23] N. E. Amidu, K. B. A. Woode, A. Owiredu, A. K. William, C. George-Boateng. An Evaluation of Toxicity and Mutagenicity of Sphenocentrumjollyanum. International Journal Pharmacology 4: $67-77,2008$

[24] M. M. Iwu. Handbook of African medicinal Plants, CRC Press.BocaRatot, Pp. 241-251, 1993.

[25] M. N. Ushijima, Y. Komoto, I. Sugizono, M. Mizuno, M. Sumihiro, M. Ichikawa and M. Hayama. Triterpene glycosides from the root of Codonopsislanceolata,Biol.Pharm.Bull, vol. 56, no. 3, pp. 308-314, 2008 .

[26] P. J. O'Shaughnessy, A. Monteiro, G. Verhoeven, K. De Gent and M. H. Abel. Effects of FSH on Testicular Morphology and Spermatogenesis in Gonadotrophin-Induced Hypogonadal Mice lacking androgen receptors. The Journal of society for Reproduction and Fertility, vol. 139, no. 1, pp. 177-184, 2010.

[27] E. V. Ikpeme, P. B. Udoh, U. B. Ekaluo, O. Udensi and B.O Asuquo. Spermicidal and Hormonal Response of Wistar Rats Treated with Ethanol Seed, Leaf and Pulp Extracts of Carica Papaya (Linn). International Journal of Recent Scientific Research, vol. 7, 155-159, 2010.

[28] P. B. Ayoola, O. O. Onawumi and O. O. Faboya. Chemical evaluation and nutritive values of Tetracarpidiumconophorum (African walnut) Edition. Journal of Pharmaceutical and Biomedical Science, vol. 11, pp. 1-4, 2011.

[29] K. O. Oyedeji, A. F. Bolarinwa and A. M. Akintola. Effect of Methanol Extract of Vernonia amygdalina on Haematological and Plasma Biochemical Parameters in Male Albino Rtas.Journal of Dental and Medical Sciences vol. 3, pp. 64-67, 2013.

[30] S. Jain, G. P. Choudhary and D. K. Jain. Medicinal plants with potential anti-fertility activity: A review. International of Green Pharmacy, vol. 9, no. 4, pp. 223-228, 2015.

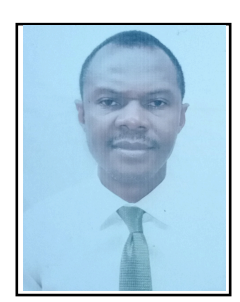

Simeon I. Egba

Place and date of birth:

Educational background: Ph.D (Medical Biochemistry), M.Sc(Medical Biochemistry), B.Sc (Medical Biochemistry), University of Nigeria Nsukka, Enugu State, Nigeria. 
